\title{
CORRESPONDENCE
}

\section{Silurian, Devonian and Old Red Sandstone on Geological Survey maps}

SIR,-At the International Geological Congress in Montreal (August 1972) the Stratigraphy Commission of the International Union of Geological Sciences (IUGS) accepted the report of its Silurian-Devonian Boundary Committee that the boundary shall be taken in Bed $20(7-10 \mathrm{~cm}$ thick) at Klonk nr Suchomasty, $45 \mathrm{~km}$ SW of Prague, Czechoslovakia. Bed 20 lies in Siluro-Devonian marine strata, and the selected boundary is at or near the base of the Zone of Monograptus uniformis uniformis.

In Britain this means that the 130-year-old problem of the boundary between the Silurian and Devonian = Old Red Sandstone systems has now been removed from the context of the original type area and solved within the confines of a fully marine sequence in accordance with most of the accepted requirements of an ideal boundary stratotype. The agreement means that the British Ludlovian-Downtonian boundary can no longer be maintained as the Silurian-Devonian boundary, therefore the statement made on behalf of the Institute of Geological Sciences by Dr P. T. Warren (1969) must now be modified.

It is reasonable to assume that in Britain the horizon of the new Silurian-Devonian boundary will not be identified by unanimous agreement for many years. This is because of the nature of the red measures that everywhere overlie identifiable basal Downtonian strata. The Downtonian-Dittonian and Dittonian-Breconian boundaries are drawn approximately where broad changes of facies occurred during the deposition of the Lower Old Red Sandstone, within the ranges of which, gradual changes in the fish fauna and plant spores can be detected. These boundaries are extremely imprecise and even the faunal changes may be mainly a symptom of the decreasingly marine character of the depositional environment as deltaic conditions migrated southwards ahead of rivers draining the 'Caledonian' continent. Even where a boundary is given a semblance of precision such as that drawn above or below the so-called main 'Psammosteus' Limestone of the Welsh Borderland (see Squirrell, 1973) there is little to convince the stratigrapher that any of these concretionary cornstones is more than locally thick or persistent. In view of this it is unlikely that either the Downtonian-Dittonian or the Dittonian-Breconian boundary will ever qualify as a satisfactory system boundary. It would indeed be pure chance if either lies very close to the horizon of the SilurianDevonian boundary as defined at Klonk, therefore the almost too obvious corollary to the Klonk agreement, i.e. that the Downtonian-Dittonian boundary should now become the 'British' Silurian-Devonian boundary, must be viewed with great caution. It is our intention to view it in this light until a great deal more soundly based evidence for the validity of correlations between marine and continental facies is brought forward.

With the above considerations in mind we have been obliged to come to the conclusion that in Britain the Klonk agreement makes it no longer possible to maintain the exact equivalence of the term Old Red Sandstone and the term Devonian, even though the former term has been used for over $\mathbf{1 3 0}$ years as a system name equally as valid as the latter. Once this basic departure from precedent is made it leaves us free to retain the base of the Downtonian as the base of the Old Red Sandstone, and this in turn means that the international decision to raise the Silurian-Devonian boundary to a level within the Lower Old Red Sandstone need cause only minimal changes to maps, sections and descriptive matter dealing with strata of this age range. In practice the term Devonian will, as in the past, seldom be applied to the Old Red Sandstone, but when it has to be applied, as for instance to vertical sections on the margin of maps, the following practice will be adopted. The Silurian bracket will be continuous up to the base of the Downtonian, above which a broken line will span the Downtonian and most of the Dittonian, thence a continuous Devonian bracket will be shown. Inside the system brackets there will be an Old Red Sandstone bracket, its base coincident with the base of the Downtonian, and all symbols and colours will remain, as now, keyed to this definitive boundary.

Geol. Mag. 110 (3), 1973, pp. 301-303. Printed in Great Britain. 
The contents of this letter have been discussed with all interested colleagues in the Institute of Geological Sciences and its publication is approved by the Director.

\section{References}

Squirrell, H. C. 1973. The Downtonian-Dittonian Boundary. $J l$ geol. Soc. 129, 205-6. Warren, P. T. 1969. The Siluro-Devonian Boundary. Geol. Mag. 106, 215-16.

Institute of Geological Sciences

J. R. EARP

5 Princes Gate

London SW7 1QN

30th January 1973

\section{The Silurian Devonian boundary}

SIR,-At the request of the editors, I enclose a short statement which summarizes the final recommendation on horizon and locality for boundary stratotype definition of the Silurian-Devonian Boundary that was made to the Commission on Stratigraphy during the meetings of the 24th International Geological Congress, in August, 1972. The full recommendation is published in Geological Newsletter of the IUGS, No. 4, 1972, pages 268-88. The statement reads as follows:

'The Committee on the Silurian-Devonian Boundary recommends that:

1. The Barrandian area of Czechoslovakia be chosen as the type area in which the Silurian-Devonian Boundary is physically defined. This area will constitute, as a whole, an international standard with which all other regions in the world may be compared.

2. Within the Barrandian area, it is further recommended that the section at Klonk near Suchomasty, as described by Chlupáč in Geological Newsletter, 1969 , No. 4 , page 333 , be designated the type section, or boundary stratotype section at which the selected physical horizon shall be defined; and that the section at Budñany near Karlštejn be designated an auxiliary type section that is positively correlatable with Klonk, but yields supplementary paleontological information.

3. That the boundary horizon in the section at Klonk shall be within the 7 to 10 centimetre thick bed No. 20 immediately below the sudden and abundant occurrence of $M$. uniformis and $M$. uniformis angustidens in the upper part of that bed.'

The section at Klonk is described in greater detail in 'The Silurian-Devonian Boundary in the Barrandian' by Ivo Chlupáč, with contributions by Hermann Jaeger and Jana Zikmundova, which was published in the Bulletin of Canadian Petroleum Geology, Volume 20, No. 1, March 1972, pages 104-74.

It is important to realize the boundary is defined at a physical horizon at a single locality. Klonk was chosen after considerable discussion by the members of the Committee. It is quite possible that there are better sections in the world, and these may become known with additional work. The Barrandian sections, however, have a great deal to recommend them, and the reasons for the choice of the Committee are made clear in the final recommendations as published. As far as possible, the Committee attempted to choose the boundary in a succession representing continuous sedimentation, and without any geological event apparent at the boundary horizon. It was chosen in relation to the zone of Monograptus uniformis, but now that the physical horizon has been chosen, the zone graptolite is no longer the defining criterion. The precise horizon within 'bed 20' referred to above will be defined more clearly in a final report supported by photographs of locality and thin sections of the bed itself.

In fact, zone fossils make their appearance in succession across the boundary, and have been found to appear in approximately the same order in five continents. 